\title{
Monitoring lactic acid production during milk fermentation by in situ quantitative proton nuclear magnetic resonance spectroscopy
}

\author{
R. Bouteille, ${ }^{*} \dagger \ddagger^{1}$ M. Gaudet, ${ }^{*} \dagger$ B. Lecanu, $\ddagger$ and H. This ${ }^{*} \dagger$ \\ *INRA, UMR 1145 Ingénierie Procédés Aliments, Group of Molecular Gastronomy, and \\ †AgroParisTech, UMR 1145 Ingénierie Procédés Aliments, Group of Molecular Gastronomy, AgroParisTech, F-75005 Paris, France \\ ¥Yoplait France, F-92641 Boulogne, France
}

\section{ABSTRACT}

When fermenting milk, lactic bacteria convert part of $\alpha$ - and $\beta$-lactoses into D- and L- lactic acids, causing a $\mathrm{pH}$ decrease responsible for casein coagulation. Lactic acid monitoring during fermentation is essential for the control of dairy gel textural and organoleptic properties, and is a way to evaluate strain efficiency. Currently, titrations are used to follow the quantity of acids formed during jellification of milk but they are not specific to lactic acid. An analytical method without the use of any reagent was investigated to quantify lactic acid during milk fermentation: in situ quantitative proton nuclear magnetic resonance spectroscopy. Two methods using in situ quantitative proton nuclear magnetic resonance spectroscopy were compared: (1) D- and L-lactic acids content determination, using the resonance of their methyl protons, showing an increase from $2.06 \pm 0.02$ to $8.16 \pm 0.74 \mathrm{~g} / \mathrm{L}$ during $240 \mathrm{~min}$ of fermentation; and (2) the determination of the $\alpha$ and $\beta$-lactoses content, decreasing from $42.68 \pm 0.02$ to $30.76 \pm 1.75 \mathrm{~g} / \mathrm{L}$ for the same fermentation duration. The ratio between the molar concentrations of produced lactic acids and consumed lactoses enabled cross-validation, as the value $(2.02 \pm 0.18)$ is consistent with lactic acid bacteria metabolism.

Key words: lactic acid, in situ quantitative nuclear magnetic resonance spectroscopy, lactic fermentation

\section{INTRODUCTION}

Milk from cows (females of Bos taurus) is a colloidal system, including an aqueous phase (63-87\% water) with fat globules in emulsion, proteins in suspension, and dissolved compounds such as $\alpha$-lactose (4-O- $\beta$ D-galactopyranosyl- $\alpha$-D-glucopyranose) and $\beta$-lactose (4- $O$ - $\beta$-D-galactopyranosyl- $\beta$-D-glucopyranose) according to Tamime and Robinson (1999). Modifications of

Received August 27, 2012.

Accepted December 16, 2012.

${ }^{1}$ Corresponding author: romain.bouteille@yoplait.fr the microstructure of milk can make different products with specific textural and organoleptic properties (Tamime and Robinson, 1999). In particular, the production of D- and L-lactic acids (2-hydroxypropanoic acids) by suitable microorganisms triggers the coagulation of casein compounds (Fox and McSweeney, 1998; Vetier et al., 2000; Lucey, 2002). The gel which is formed is then called fermented milk (FAO/WHO, 2010). When symbiotic cultures of Streptococcus thermophilus and Lactobacillus delbrueckii ssp. bulgaricus are used, fermented milk is named yogurt (FAO/WHO, 2010). As national legislations give slightly different definitions of dairy gels (DG), taking into account manufacturing processes, bacterial flora viability, ingredient origin, and physicochemical criteria such as composition (Pernoud et al., 2005), we use here the term DG to designate any gel obtained by milk coagulation due to lactic acid bacteria activity. The usual manufacturing process of DG is to add 1.5 to $3 \%$ of a culture of starter microorganisms to milk before incubation at 42 to $45^{\circ} \mathrm{C}$ for about $3 \mathrm{~h}$ (Tamime and Robinson, 1999). The obtained gel has a $\mathrm{pH}$ between 4.2 and 4.7, and contains 0.7 to $1.1 \%$ D- and L-lactic acids (Pernoud et al., 2005). Indeed, lactic bacteria convert $\alpha$ - and $\beta$-lactoses into D- and L-lactates via homofermentation using the EmbdenMeyerhof glycolysis pathway (Carr et al., 2002). By a series of enzymatic reactions in anaerobic conditions, microorganisms produce 2 lactate moieties for $1 \alpha$ - or $\beta$-lactose molecule, leading to the production of energy under the form of adenosine triphosphate (Tamime and Robinson, 1999; Carr et al., 2002; Pernoud et al., 2005). Through symporters, these 2 lactates and 2 free protons are expelled from the bacterial cells to the external medium (Sodini and Béal, 2003), the ejection of protons causing a $\mathrm{pH}$ decrease. The cologarithm of the acid dissociation constant between D- or L-lactic acids and their conjugated bases (lactate anions) being 3.86 (Salaün et al., 2005), the predominant form of this acid-base pair in DG is lactate and not lactic acid, even though literature often use the term lactic acid (Tamime and Robinson, 1999; Güzel-Seydim et al., 2000; Pernoud et al., 2005). Both D- and L-enantiomers of 
lactic acid are produced, with the proportion of L-lactic acid rising from 40 to $70 \%$ of the total lactic acid content (Pernoud et al., 2005), but, as both enantiomers have the same acid-base properties (Atkins, 1989), the term lactic acid will be used in this study to designate both D- and L-lactic acids. In the same way, the term lactose will be used to designate both $\alpha$ - and $\beta$-lactoses.

When the lactic acid quantity increases (about $2 \mathrm{~g} / \mathrm{L}$ per hour, depending on experimental conditions), the $\mathrm{pH}$ decreases from about 6.8 to about 4.6 (Pernoud et al., 2005). Milk acidification during fermentation changes the physicochemical environment of casein micelles (Özen and Özilgen, 1992; Famelart et al., 1996; Gastaldi et al., 1997; Vetier et al., 2000), triggering the gelation of milk (Salaün et al., 2005). Also, the increase in lactic acid content gives DG an acidic taste (Grunert et al., 2000).

Monitoring lactic acid content is, therefore, essential for DG making, as it is an indicator of fermentation (Alais, 1984; Torrestiana et al., 1994). It is also a way to evaluate strain efficiency (Accolas et al., 1977). Lactic acid content is usually determined by acid-base titration (Alais, 1984; Tamime and Robinson, 1999). However, there is a lack of a standard procedure for acid-base titrations, as a variety of titration methods are used (Torrestiana et al., 1994). Most of them are based on an endpoint titration using sodium hydroxide as a base. The quantity of the base necessary to shift the $\mathrm{pH}$ value from the initial value of the studied sample to a set $\mathrm{pH}$ value (determined by the discoloration of a color indicator or measured by a $\mathrm{pH}$ meter) leads to so-called titratable acidity. This titratable acidity is then commonly expressed in Dornic degrees, in Soxhlet-Henkel degrees, or in Thoerner degrees (Pernoud et al., 2005). However, titrations are not easy to implement on production lines, and they require the use of chemicals. Moreover, as the added alkali can react with all kinds of acidic functions of compounds present in DG, the method is not lactic acid specific. Hence, quantifying lactic acid is an important scientific and technologic goal.

A promising technique is in situ quantitative proton nuclear magnetic resonance spectroscopy (isq ${ }^{1} \mathbf{H}$ NMR) in the frequency domain. Indeed, isq ${ }^{1} \mathrm{H}$ NMR gave interesting results for the quantitative determination (Fan, 1996; Tardieu et al., 2009) of solutes in the liquid phase of gels (Weberskirch et al., 2011). This analytical method is easy to implement (no preliminary treatments and no use of organic solvents or chemicals), nondestructive, and fast $(\sim 20 \mathrm{~min})$, making it suitable for fermentation monitoring. The implementation of ${ }^{1} \mathrm{H}$ NMR according to the electronic reference to access in vivo concentrations (ERETIC) method has been reported to determine lactic acid content during cofer- mentation of glucose and citrate by Lactococcus lactis ssp. lactis (Silvestre et al., 2001). This method is based on the use of a signal produced by an electronic device as a reference for quantification. However, preliminary treatments of the samples were required, leading to potential errors in estimating lactic acid content. The objective of the current study is to apply NMR spectroscopy to quantify the production of lactic acid during lactic fermentation, investigating in situ conditions. Thereby, we used isq ${ }^{1} \mathrm{H}$ NMR to determine the quantity of lactic acid during milk fermentation using directly the NMR resonances corresponding to this chemical species. We validated these results, following simultaneously the content in lactose, as the quantity of produced lactic acid, when expressed in mol, should be twice the quantity of lactose consumed by lactic acid bacteria, according to their metabolic pathway.

\section{MATERIALS AND METHODS}

\section{Chemicals}

Deuterium oxide 99.9 atom\% $\mathrm{D} \quad\left(\mathbf{D}_{2} \mathbf{O}\right), 3$-(trimethylsilyl)propionic-2,2,3,3- $\mathrm{d}_{4}$ acid, sodium salt $98 \%$, and sodium hydroxide $98.0 \%$ were purchased from Sigma-Aldrich (Steinheim, Germany). A racemic mix of (R)- and (S)-2-hydroxypropanoic acids (DL-lactic acids) was supplied by Purac Biochem (Barcelona, Spain). 4-O- $\beta$-D-Galactopyranosyl- $\alpha-D-$ glucopyranose ( $\alpha$-lactose) monohydrate containing $3 \%$ of $4-O-\beta-\mathrm{D}-$ galactopyranosyl- $\beta$-D-glucopyranose ( $\beta$-lactose) was purchased from Sigma Chemical (St Louis, MO). The purity of all chemicals was checked using NMR spectroscopy.

\section{Standard Solutions}

To make calibration curves for lactic acid and lactose, 2 initial solutions containing, respectively, 57 and 185 $\mathrm{g} / \mathrm{L}$ were prepared in $\mathrm{D}_{2} \mathrm{O}$. By dilution, respectively 5 standard solutions $\left(\mathbf{S}_{\mathrm{LA}}\right)$ and 4 standard solutions $\left(\mathbf{S}_{\mathbf{L}}\right)$ were obtained, with concentrations in lactic acid ranging from 0.925 to $15.431 \mathrm{~g} / \mathrm{L}$ and in lactose ranging from 0.973 to $102.804 \mathrm{~g} / \mathrm{L}$. These concentration ranges were chosen in accordance with the average concentrations of lactic acid $(10.8 \mathrm{~g} / \mathrm{L})$ and lactose (between 40 and $60 \mathrm{~g} / \mathrm{L}$ ) in DG (Belitz et al., 2009).

\section{Fermentation}

Dairy gels were prepared from cow milk (organic UHT skimmed cow milk; Lactel, Change, France) containing $3.2 \%$ proteins, $4.8 \%$ saccharides, and less than $0.1 \%$ lipids (checked by ${ }^{1} \mathrm{H}$ NMR). Milk was heated in 
an oven at $45^{\circ} \mathrm{C}$ (precision of $1^{\circ} \mathrm{C}$ ) for $20 \mathrm{~min}$. Then, a mix of lactic acid bacteria (Lactobacillus bulgaricus and Streptococcus thermophilus; CGD Laboratoire Yalacta SA, Caen, France) was added under manual agitation (mass percentage: $0.40 \%$ ). Inoculated milk, in capped beakers, was then heated at $45^{\circ} \mathrm{C}$ (precision of $1^{\circ} \mathrm{C}$ ) for $4 \mathrm{~h}$ in an oven. Every $30 \mathrm{~min}$, a sample of $30 \mathrm{~g}$ of inoculated milk was taken in order to (1) measure the $\mathrm{pH}$ using a $\mathrm{pH}$ meter (CyberScan $\mathrm{pH} 1100$ with ATC probe; Eutech Instruments Europe BV, Nijkerk, the Netherlands), following official measurement methods (Wrolstad, 2005; Sadler and Murphy, 2010); (2) determine the titratable acidity (ISO, 2012); and (3) be analyzed by isq ${ }^{1} \mathrm{H}$ NMR (as described below). According to the International Organization for Standardization (ISO) standard ISO/TS11869 (ISO, 2012), the titratable acidity was determined using the following potentiometric method: a test portion of DG (10.00 $\mathrm{g})$, added to deionized water $(10.00 \mathrm{~g})$ at $22^{\circ} \mathrm{C}\left( \pm 1^{\circ} \mathrm{C}\right)$ in a water bath (as checked by $J$ thermocouples), was homogenized ( 2 min at 9,000 rpm using a T25 digital Ultra-Turrax disperser with a disperser tool S25 N-25 F; Imlab, Lille, France). Under manual agitation, the suspension was titrated potentiometrically to determine the amount of sodium hydroxide solution $[\mathrm{NaOH}$ concentration $\left(c_{\mathrm{NaOH}}\right)=0.100 \mathrm{~mol} / \mathrm{L}$, in deionized water, freshly made] required to reach $\mathrm{pH} 8.30 \pm 0.01$ (stable for $5 \mathrm{~s}$ ).

From the oven, the samples were stored at $4^{\circ} \mathrm{C}$ $\left( \pm 1^{\circ} \mathrm{C}\right)$ in closed glass beakers, the storage time not exceeding $4 \mathrm{~h}$ to minimize the action of lactic bacteria after removal (Pernoud et al., 2005). For temperature stabilization, before each analysis, samples were put in a water bath $\left(20 \pm 1^{\circ} \mathrm{C}\right)$ for $10 \mathrm{~min}$. Three different fermentations were made following this method and all measurements were made in triplicate.

\section{isq ${ }^{1} H$ NMR}

A $300-\mathrm{MHz}$ Bruker BioSpin NMR spectrometer (Bruker BioSpin GmbH, Karlsruhe, Germany) was used. Each spectrum was recorded at $20.00^{\circ} \mathrm{C}$ (SD: $0.01^{\circ} \mathrm{C}$ ). Spectra were Fourier transformed with $0.3-\mathrm{Hz}$ line broadening and baseline corrected using XWinNMR 3.5 software (Bruker BioSpin GmbH). About 700 mg of each sample (Cazor et al., 2006; Tardieu et al., 2010) was introduced into an NMR tube (5-mm borosilicate glass; Sigma-Aldrich, St. Louis, MO), the mass of the sample being weighed with a precision of 0.1 mg. As internal reference for quantification (Tardieu et al., 2009), the same homemade closed capillary tube $(200 \mu \mathrm{L}$; SMI, Emeryville, CA) filled with $65.0 \mathrm{mg}$ of a solution of $5 \% 3$-(trimethylsilyl) propionic-2,2,3,3- $\mathrm{d}_{4}$ acid in $\mathrm{D}_{2} \mathrm{O}$ was introduced into each NMR tube before acquisition. Quantification can be performed because each NMR resonance area is proportional to the number of nuclei that are responsible of the corresponding signal (Malz and Jancke, 2005). The analysis of each sample was performed using $\mathrm{D}_{2} \mathrm{O}$ contained in the capillary tube as an internal lock. Each spectrum was acquired from 32 scans of 32,768 data points with a spectral width of $6 \mathrm{kHz}$ and an acquisition time of 2.7 $\mathrm{s}$, a recycle delay of $25 \mathrm{~s}$ per scan, and a flip angle of $90^{\circ}$ (pulse length: $8.2 \mu \mathrm{s}$ ), to allow complete relaxation (Silvestre et al., 2001). Acquisitions required about 15 min per sample. For each spectrum, resonances were integrated 3 times by tangent skimming (Chesler and Cram, 1971; Dyson, 1998).

\section{RESULTS AND DISCUSSION}

A singlet at 4.85 and $4.89 \mathrm{ppm}$ can be observed on all spectra of $\mathrm{S}_{\mathrm{LA}}$ and $\mathrm{S}_{\mathrm{L}}$, respectively. This is due to water. The small difference in chemical shift is assumed to be due to the pH (Tardieu et al., 2010), but it was too small to give reliable $\mathrm{pH}$ measurements. As an illustration, the ${ }^{1} \mathrm{H}$ NMR spectra of a standard solution of lactic acid $\left(10.425 \mathrm{~g} / \mathrm{L}\right.$, in $\left.\mathrm{D}_{2} \mathrm{O}\right)$ and of lactose (11.037 $\mathrm{g} / \mathrm{L}$, in $\left.\mathrm{D}_{2} \mathrm{O}\right)$ are displayed in Figure 1 . The area of the resonance of water is the same on all spectra $(\mathrm{CV}$ $<0.010)$. The resonance at $4.76 \mathrm{ppm}$ appearing on all spectra of $\mathrm{S}_{\mathrm{LA}}$ and $\mathrm{S}_{\mathrm{L}}$ is due to water contained in the capillary tube, due to the use of $\mathrm{D}_{2} \mathrm{O}$. Moreover, the ${ }^{1} \mathrm{H}$ NMR spectra of $\mathrm{S}_{\mathrm{LA}}$ (Figure 1A) show 2 resonances due to lactic acid, both D- and L-lactic acids having identical NMR spectra (Clayden et al., 2012): 4.10 ppm, quadruplet, $J=7.03 \mathrm{~Hz}$, asymmetric $\alpha$-hydroxymethylene proton; $1.44 \mathrm{ppm}$, doublet, $J=7.02 \mathrm{~Hz}$, methyl protons (Fan, 1996). Their areas increase in function of the concentration of lactic acid. Figure 2A shows the evolution of the area of the doublet at $1.44 \mathrm{ppm}\left(\boldsymbol{A}_{\boldsymbol{d}}\right)$ as a function of the concentration of lactic acid; $A_{d}$ was used for calibration (linear regression model: $y=1.146 x$; $\left.\mathrm{R}^{2}=0.999\right)$, as this resonance does not overlap with resonances obtained for milk under gelation samples, as described below.

For $\mathrm{S}_{\mathrm{L}}, 5$ resonances appear (Figure 1B): $5.16 \mathrm{ppm}$, doublet, $J=3.73 \mathrm{~Hz}$, anomeric $\mathrm{H}_{1}$-glucose methylene proton of $\alpha$-lactose; $4.60 \mathrm{ppm}$, doublet, $J=7.88 \mathrm{~Hz}$, anomeric $\mathrm{H}_{1}$-glucose methylene proton of $\beta$-lactose; $4.37 \mathrm{ppm}$, doublet, $J=7.78 \mathrm{~Hz}, \mathrm{H}_{2}$-glucose methylene protons of both $\alpha$ - and $\beta$-lactoses; 3.85 to $3.44 \mathrm{ppm}$, multiplet, tetrahydropyrane protons, methylene protons of $\alpha$ - and $\beta$-lactoses and $\mathrm{H}_{2}$-glucose methylene protons of $\alpha$-lactose; and $3.22 \mathrm{ppm}$, triplet, $J=8.24 \mathrm{~Hz}, \mathrm{H}_{2^{-}}$ glucose methylene protons of $\beta$-lactose (Bubb, 2003). Their areas increase with the concentration of lactose. Figure 2B shows the evolution of the area $\left(\boldsymbol{A}_{\text {cor }}\right)$ of 

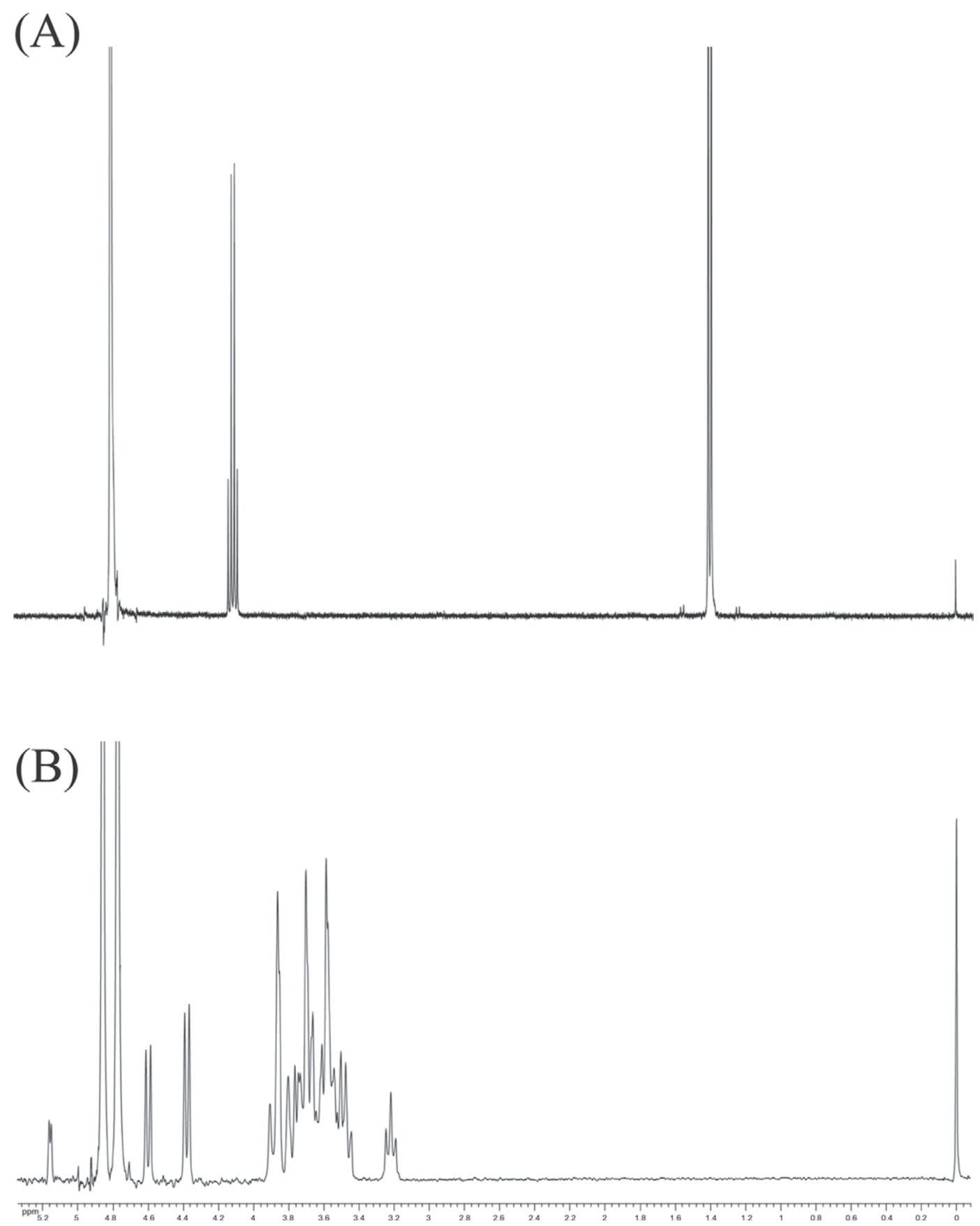

Figure 1. Nuclear magnetic resonance spectra of the standard solutions of $10.425 \mathrm{~g} / \mathrm{L}$ of lactic acid (A) and $11.037 \mathrm{~g} / \mathrm{L}$ of lactose (B) in deuterium oxide, the resonance of 3 -(trimethylsilyl) propionic-2,2,3,3- $\mathrm{d}_{4}$ acid being used as internal reference (chemical shift: 0 ppm).

the complex of resonances constituted by the multiplet between 3.85 and $3.44 \mathrm{ppm}$, and by the triplet at 3.22 ppm. The area $A_{\text {cor }}$ was used for calibration (linear regression model: $\left.y=1.157 x ; \mathrm{R}^{2}=0.999\right)$, avoiding considering tautomer equilibrium, as $A_{\text {cor }}$ represents the resonance of both $\alpha$ - and $\beta$-lactose corresponding protons. Modeling by a linear function of the area of the doublet at $4.37 \mathrm{ppm}(J=7.78 \mathrm{~Hz})$, due to the $\mathrm{H}_{2^{-}}$ glucose methylene protons of both $\alpha$ - and $\beta$-lactoses, was used for validation (CV of the slope: $8 \cdot 10^{-4}$, respecting the calibration line made from $\left.A_{c o r}\right)$. In Figure 2 , linear regression models based on $A_{d}$, and $A_{c o r}$, as a function of the concentration in lactic acid and in lactose, respectively, are displayed with their $95 \%$ confidence intervals. Indeed, by multiplying the standard error of the regression with a 2-tailed Student's $t$-value 

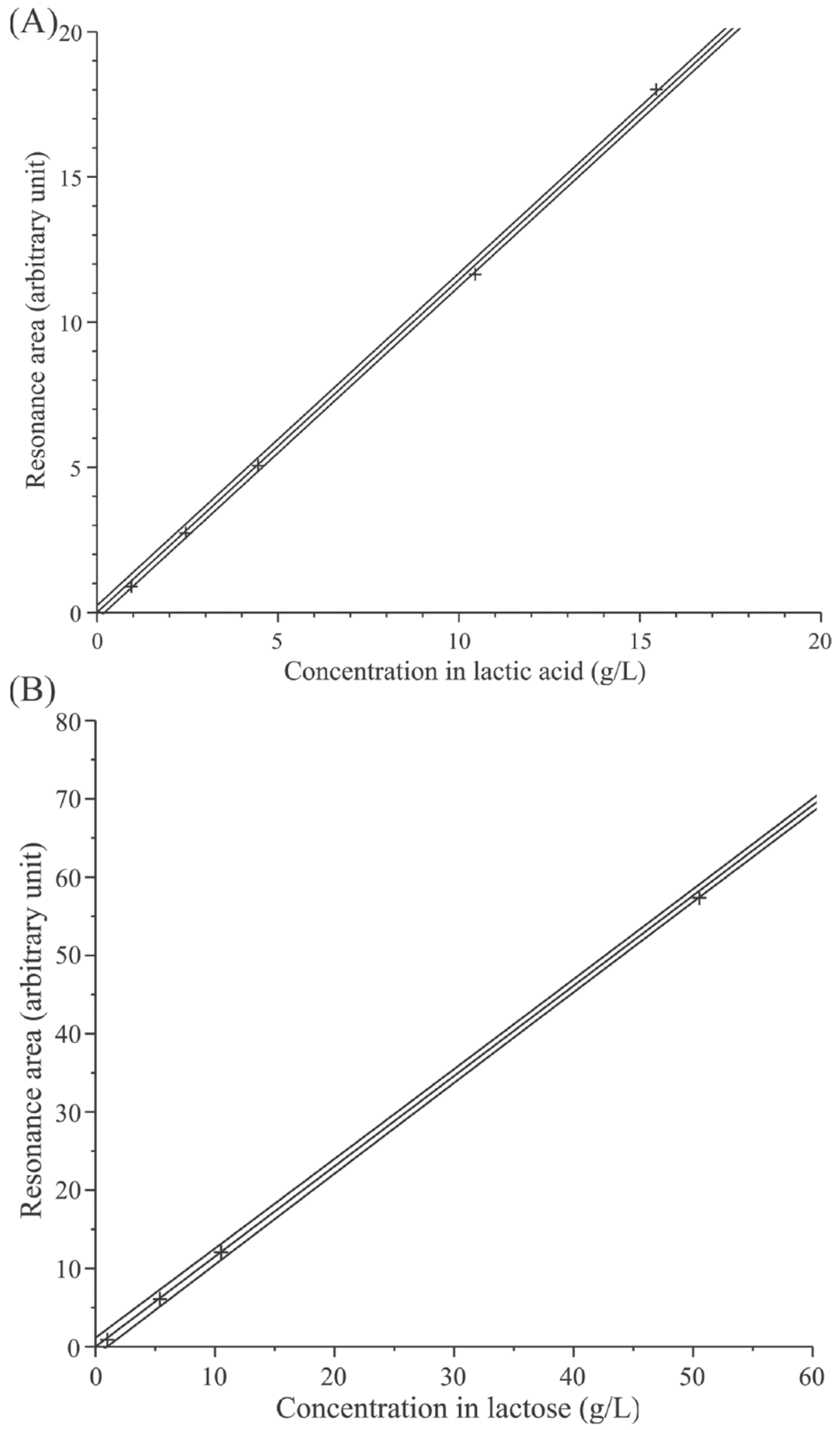

Figure 2. Experimental data with their linear modeling of (A) the area of the doublet at 1.44 ppm observed on the spectra of lactic acid standard solutions as a function of the concentration in lactic acid, and (B) the area of the complex of resonances constituted by the multiplet between $3.85 \mathrm{ppm}$ and $3.44 \mathrm{ppm}$, and by the triplet at $3.22 \mathrm{ppm}$, observed on the spectra of lactose standard solutions as a function of the concentration in lactose. Standard deviations of the experimental data (resonance areas and concentrations) are smaller than the size of data points. The envelop curves around the lines define the $95 \%$ CI (95\% of all the possible calibration lines are included between the upper and lower limits). 
$(\alpha=0.05, \mathrm{df}=\mathrm{n}-2$, with $\mathrm{n}$ the number of standard solutions), as data were considered normally distributed, the $95 \%$ confidence interval was determined: $95 \%$ of all the possible calibration lines are included between the upper and lower limits of the interval (Miller and Miller, 1988; Matsuda et al., 2001). This confidence interval was then used to estimate uncertainties on lactic acid and lactose content for each replicate.

Figure 3 shows the spectra for milk at different times after lactic acid bacteria inoculation. In these spectra, the resonances at the same chemical shifts as the ones obtained for $\mathrm{S}_{\mathrm{LA}}$ increase with time, and the resonances at the same chemical shifts as the ones obtained for $\mathrm{S}_{\mathrm{L}}$ decrease with time. The area of the large resonance of water is about 10 times larger than other resonance areas, but it does not prevent the determination of resonance areas around $1.4 \mathrm{ppm}$ and between 3.4 and $4.0 \mathrm{ppm}$, where lactic acid protons and lactose pro- tons, respectively, appear (Fan, 1996; Bubb, 2003). The calibration lines enable the calculation of the quantities of lactose and lactic acid during fermentations. These quantities are displayed in Figure 4 for each replicate of the experiment (uncertainties of lactic acid and lactose quantities were estimated using the $95 \%$ confidence interval), with $\mathrm{pH}$ measurements also being reported. The general shape of the obtained curves, the value of the concentrations, and the ratio between produced lactic acid and consumed lactose are in accordance with lactic fermentation (Alais, 1984; Torrestiana et al., 1994; Belitz et al., 2009), as discussed below. Quantities will be displayed as the average values of the 3 replicates with their standard deviations for the following part of the article.

Indeed, the initial concentration of lactose was 42.68 $\pm 0.02 \mathrm{~g} / \mathrm{L}$. This value is in accordance with the literature, which indicates that cow milk lactose content

(A)

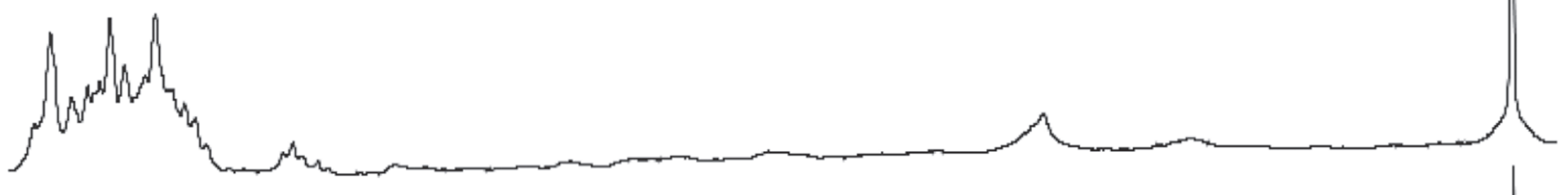

(B)
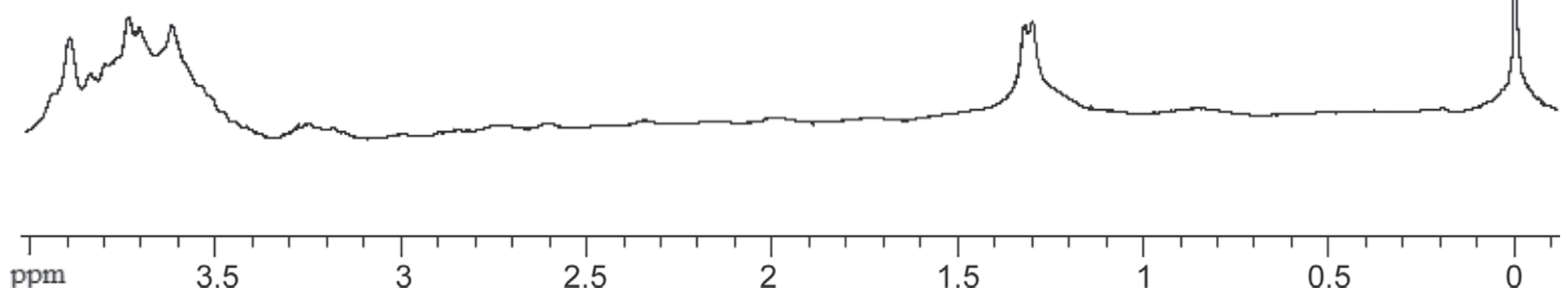

Figure 3. In situ quantitative proton nuclear magnetic resonance spectra of milk under gelation recorded at inoculation time (A) and 240 min after inoculation (B): the area of the resonance of the doublet at $1.44 \mathrm{ppm}$ increases with time while the area of the resonance between 3.85 ppm and 3.22 ppm decreases with time. 

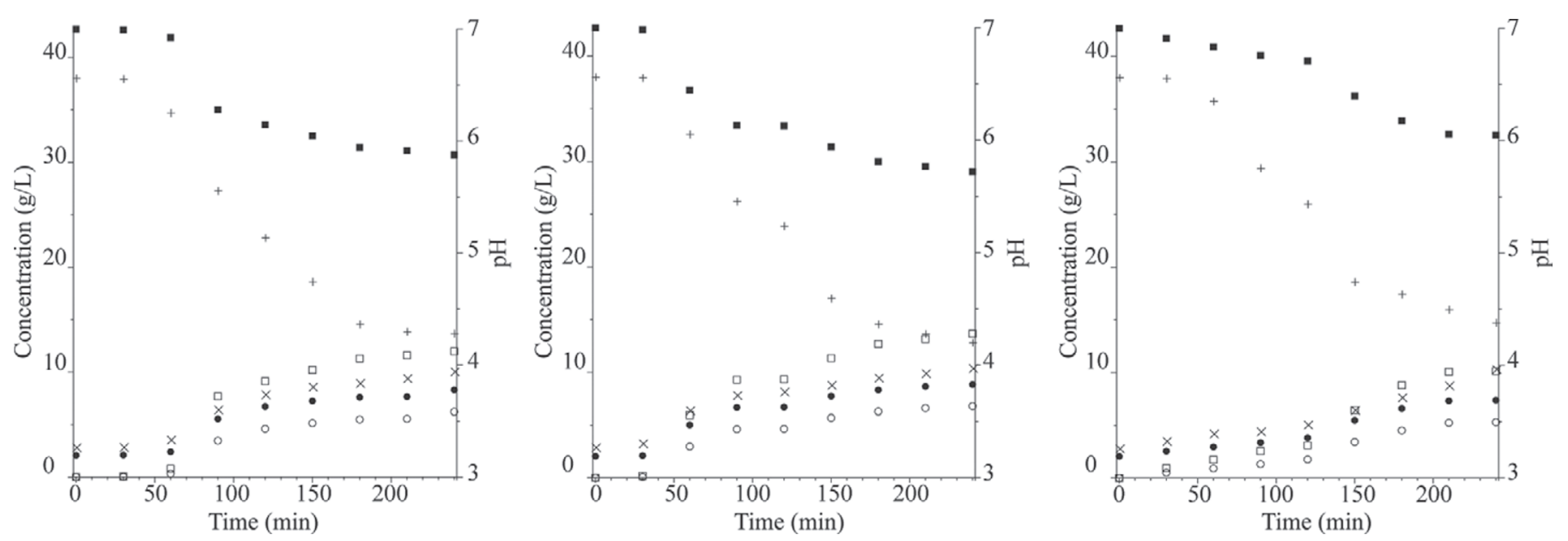

Figure 4. Concentration, in $\mathrm{g} / \mathrm{L}$, of lactic acid $(\bullet)$ and lactose $(\mathbf{\square})$ in the milk-under-gelation samples for the 3 replicates (panels). The quantities of the produced lactic acid $(\bigcirc)$ and of the consumed lactose $(\square)$ are displayed, as well as the results from the titration method $(\times)$, expressed as lactic acid corresponding concentrations, and from the $\mathrm{pH}$ measurements $(+)$. The standard deviations for the titratable acidity (maximal value: $0.52 \mathrm{~g} / \mathrm{L}$ ), and for the $\mathrm{pH}$ measurements (maximal value: $0.03 \mathrm{pH}$ units), are smaller than the size of data points. The uncertainties for concentrations determined by nuclear magnetic resonance measurements, considering the 95\% CI around calibration lines (maximal value: $1.2 \mathrm{~g} / \mathrm{L}$ ), are also smaller than the size of data points.

is included in the range of 4 to $6 \%$ in terms of mass proportion of milk (Belitz et al., 2009). The mean of the final concentrations in lactose for the 3 replicates was $30.76 \pm 1.75 \mathrm{~g} / \mathrm{L}$, in accordance with the literature (Belitz et al., 2009). The initial concentration of lactic acid was $2.06 \pm 0.02 \mathrm{~g} / \mathrm{L}$. This value is $13 \%$ higher than the average concentration $(1.8 \mathrm{~g} / \mathrm{L})$ given in the literature (Belitz et al., 2009). A production of lactic acid during thermal treatment and storage (UHT milk being used for the experiments) can be assumed. The mean of the final concentrations in lactic acid for the 3 replicates was $8.16 \pm 0.74 \mathrm{~g} / \mathrm{L}$, in accordance with the literature, which indicates a range of 0.7 to $1.1 \%$ (Belitz et al., 2009).

The results from the titration method (displayed in Figure 4) were expressed as lactic acid corresponding concentrations $\left(c_{L A}\right.$, in $\left.\mathrm{g} / \mathrm{L}\right)$ using the following formulae (Tamime and Robinson, 1999):

$$
c_{L A}=d \times M_{L A} \times c_{N a O H} \times V / m
$$

where $d$ is the mass density in grams per liter of DG; $M_{L A}$ is the molar mass in grams per mole of lactic acid; $c_{\mathrm{NaOH}}$ and $V$ are, respectively, the concentration in moles per liter and the volume in liters of the sodium hydroxide solution used as a titrant; and $m$ is the mass in grams of the test portion of DG that was titrated. According to Tamime and Robinson (1999), the following values were considered: $d=1,040 \mathrm{~g} / \mathrm{L}$ and $M_{L A}=$ $90.08 \mathrm{~g} / \mathrm{mol}$; the values of $c_{\mathrm{NaOH}}$ and $m$ were determined by the experimental procedure (ISO, 2012).
Figure 5 shows the difference between the titratable acidity, expressed as lactic acid content, and the lactic acid content determined by isq ${ }^{1} \mathrm{H}$ NMR for the 3 replicates. The average value was $0.81 \pm 0.03 \mathrm{~g} / \mathrm{L}$ at time $t=0 \mathrm{~min}$ and increased with time to reach $2.31 \pm 0.62$ $\mathrm{g} / \mathrm{L}$ at $240 \mathrm{~min}$, in accordance with the values reported by Dave and Shah (1997) who compared the titratable acidity and the lactic acid content determined by HPLC for yogurts made from 4 commercial starter cultures. As reported by Salaün et al. (2005), the complex set of acid-base equilibriums, which involved several compositional factors, including small constituents (inorganic phosphate, citrate, and organic acids) and milk proteins (caseins and whey proteins), explained this difference, the higher values for titratable acidity being consistent with the fact that titrations are not lactic acid specific.

The quantities of lactic acid and lactose did not vary greatly during the first $30 \mathrm{~min}$ : the lactic acid content increased by $0.20 \pm 0.07 \mathrm{~g} / \mathrm{L}$ and the lactose content decreased by $0.39 \pm 0.17 \mathrm{~g} / \mathrm{L}$, which corresponds to a latency period well described in the literature. Then, between 30 and $180 \mathrm{~min}$ of fermentation time, the concentration of lactose sharply decreased (10.52 \pm $2.40 \mathrm{~g} / \mathrm{L}$ ), whereas the quantity of lactic acid deeply increased $(5.23 \pm 1.11 \mathrm{~g} / \mathrm{L})$. Finally, each curve reached a plateau. This behavior is consistent with milk fermentation (Silvestre et al., 2001; Pernoud et al., 2005), according to several studies based on mathematical models (Payot et al., 1999; Schepers et al., 2002; Biazar et al., 2003). The comparison of concentration values between the different fermentations profiles shows some 


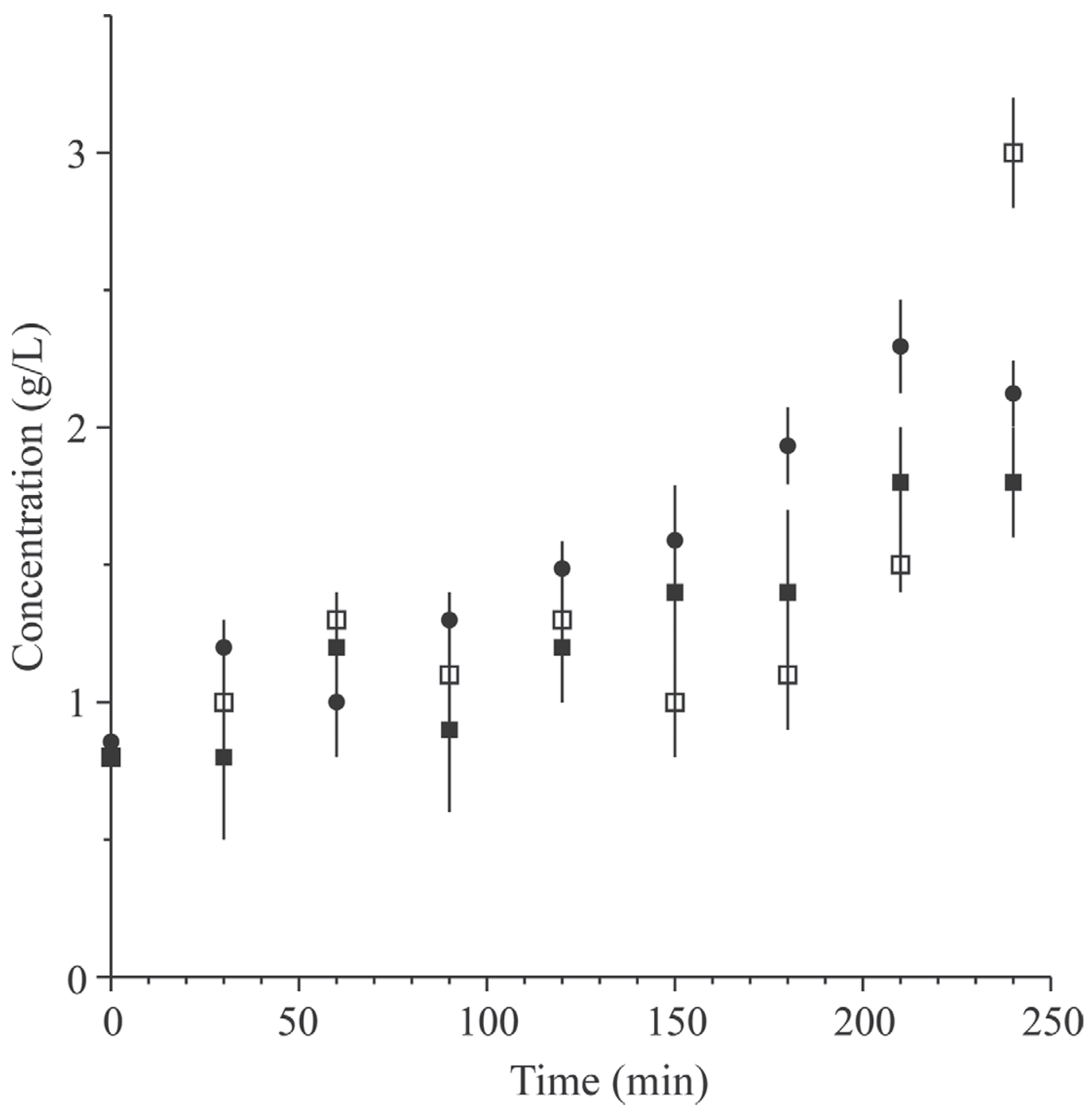

Figure 5. Difference between titratable acidity and lactic acid content determined by nuclear magnetic resonance (NMR) as a function of time for replicate $1(\boldsymbol{\bullet})$, replicate $2(\boldsymbol{\square})$, and replicate $3(\square)$. Error bars were constructed by considering standard deviations for titratable acidity and uncertainties calculated from the $95 \%$ CI of calibration lines for NMR determined lactic acid content.

differences. They can mainly be explained by a difference of the starter culture even if the same strain was used (Pernoud et al., 2005). Finally, the average ratio between the produced lactic acid and the consumed lactose was $2.02 \pm 0.18$ (mean and standard deviation of the quantities, expressed in moles, obtained for the 3 replicates of the experiment, at each considered time except inoculation time). This is in accordance with lactic bacteria metabolism (Carr et al., 2002; Pernoud et al., 2005).

This validation step showed that no decreased NMR visibility of lactic acid seemed to occur, in spite of the protein content of the samples (Chatham and Forder, 1999). Indeed, this possibility of a decrease in NMR lactic acid visibility, leading to possible underestimation of lactic acid content during NMR analysis, was based on the assumption of the immobilization of the interacting compound by nonspecific binding, dependent on the tertiary structure of the protein. This assumption was made by Chatham and Forder (1999) in the case of lactic acid in presence of blood serum albumin whose concentration in milk is low: $0.1 \mathrm{~g} / \mathrm{L}$ (Fox and Kelly, 2003). Denaturation of proteins by thermal treatment or in acidic medium $(\mathrm{pH}=2)$ was assumed to suppress the decrease in NMR visibility of lactic acid (Silvestre et al., 2001). In our study, the milk used was previously treated by UHT (i.e., $>135^{\circ} \mathrm{C}$ for 1 to $2 \mathrm{~s}$; Tamime and Robinson, 1999), which might have partially denatured proteins (Oldfield et al., 1998), explaining the full visibility of lactic acid. Moreover, when lactic acid binds 
to proteins, forces can act on the methyl group, the hydroxyl group, and the carboxylic acid group of lactic acid. In the case of the involvement of methyl groups in the binding mechanism, London dispersion forces would be involved, having a low average energy $(\sim 2 \mathrm{~kJ} / \mathrm{mol}$; Vollhardt and Shore, 1995). In experiments with BSA, lactic acid was studied along with alanine (Chatham and Forder, 1999), this amino acid also having a lateral methyl group similar to lactic acid; as no decreased NMR visibility of alanine was observed, it could be concluded that hydrophobic forces were not involved. It would then remain the assumption of an involvement of the polar part of lactic acid in the binding with proteins. In case of hydrogen bonds, which could occur between atoms of either the hydroxyl group or carboxylic acid group of lactic acid and proteins, the energy of interaction would be in the range of 10 to $30 \mathrm{~kJ} / \mathrm{mol}$ (Vollhardt and Shore, 1995). Then, when $\mathrm{pH}$ decreases, as lactic acid gets protonated, the number of hydrogen bonds should increase, enhancing the protein-binding effect and, consequently, the NMR visibility of lactic acid should decrease with $\mathrm{pH}$. However, it was shown that the NMR visibility of lactic acid in a proteinaceous solution was higher at $\mathrm{pH} 2.0$ than at $\mathrm{pH}$ 6.2. The denaturation of proteins could have an effect, but as lactic acid is a small molecule, the assumption that the binding interaction forces between proteins and lactic acid are not hydrogen bonds can also be made. The binding effect is then observed when the $\mathrm{pH}$ is above the cologarithm of the lactic acid dissociation constant (3.86), the $\mathrm{pH}$ range where lactate anions are the main species (Salaün et al., 2005). The negative charge on the oxygen atom of the carboxylic group could then be involved in interactions of Keesom forces (4-21 kJ/ $\mathrm{mol})$, or even ionic bonds $(250 \mathrm{~kJ} / \mathrm{mol})$, with proteins (Vollhardt and Shore, 1995). As a consequence, the binding sites of the proteins should be electrophilic sites. In the case of milk-under-gelation samples, lactate is not the only nucleophilic species; in particular, anions such as phosphate species $(1,500 \mathrm{mg} / \mathrm{L}$; Fox and McSweeney, 1998) might be in competition to bind protein electrophilic sites (Clayden et al., 2012). Steric considerations lead to the assumption that small anions will be favored to interact with proteins, more than lactate.

As a whole, the binding of lactate should be very limited, explaining that no decrease in NMR visibility of milk-under-gelation samples was observed when monitoring lactic acid by isq ${ }^{1} \mathrm{H}$ NMR. This hypothesis is in accordance with the literature, as Silvestre et al. (2001) did not observe decreased NMR visibility when adding a small amount of phosphate, even if those authors attributed this effect to the denaturation of some proteins caused by $\mathrm{pH}$ lowering.

\section{CONCLUSIONS}

This study confirms that isq ${ }^{1} \mathrm{H}$ NMR is an easy-toimplement method for monitoring lactic acid production during lactic acid fermentation, with uncertainties smaller than $5.0 \%$ for lactic acid content and smaller than $3.0 \%$ for lactose content when estimated from the $95 \%$ confidence intervals of calibration lines. Two methods were used to determine lactic acid content: (1) a direct method based on the increase in the areas of the lactic acid resonances and (2) an indirect method based on the decrease in the areas of the lactose resonances, which helps for validations. The simplicity and quickness of implementation of isq ${ }^{1} \mathrm{H}$ NMR are important advantages, as no preparation of samples and no organic solvent are needed. In situ quantitative proton nuclear magnetic resonance spectroscopy is then a helpful method that could be used for several further purposes: (1) to control DG manufacturing processes and storage by determination of lactic acid content; (2) to study microorganisms, in particular by evaluating bacteria strains; and (3) to better understand acidic taste in DG, as lactic acid content can be measured with no influence of other compounds (such as polycarbohydrates).

\section{ACKNOWLEDGMENTS}

The authors thank Purac Biochem (Barcelona, Spain) for kindly supplying dairy starting materials. The project was partly funded by Yoplait France (Boulogne, France).

\section{REFERENCES}

Accolas, J. P., R. Bloquel, R. Didienne, and J. Regnier. 1977. Propriétés acidifiantes des bactéries lactiques thermophiles en relation avec la fabrication de yoghourt. Lait 57:1-23.

Alais, C. 1984. Science du lait. 4th ed. Edition SEPAIC, Paris, France.

Atkins, P. 1989. General Chemistry. Scientific American Books, New York, NY.

Belitz, H.-D., W. Grosch, and P. Schieberle. 2009. Food Chemistry. 4th ed. Springer-Verlag, Berlin-Heidelberg, Germany.

Biazar, J., M. Tango, E. Babolian, and R. Islam. 2003. Solution of the kinetic modeling of lactic acid fermentation using Adomian decomposition method. Appl. Math. Comput. 144:433-439.

Bubb, W. A. 2003. NMR spectroscopy in the study of carbohydrates: Characterizing the structural complexity. Concepts in Magnetic Resonance A 19A:1-19.

Carr, F. J., D. Chill, and N. Maida. 2002. The lactic acid bacteria: A literature survey. Crit. Rev. Microbiol. 28:281-370.

Cazor, A., C. Deborde, A. Moing, D. Rolin, and H. This. 2006. Sucrose, glucose, and fructose extraction in aqueous carrot root extracts prepared at different temperatures by means of direct NMR measurements. J. Agric. Food Chem. 54:4681-4686.

Chatham, J. C., and J. R. Forder. 1999. Lactic acid and protein interactions: Implications for the NMR visibility of lactate in biological systems. Biochim. Biophys. Acta 1426:177-184.

Chesler, S. N., and S. P. Cram. 1971. Effect of peak sensing and random noise on the precision and accuracy of statistical moment analyses from digital chromatographic data. Anal. Chem. 43:1922-1933. 
Clayden, J., N. Geeves, and S. Warren. 2012. Organic Chemistry. 2nd ed. Oxford University Press, Oxford, UK.

Dave, R. I., and N. P. Shah. 1997. Viability of yoghurt and probiotic bacteria in yoghurts made from commercial starter culture. Int. Dairy J. 7:31-41.

Dyson, N. A. 1998. Chromatographic Integration Methods. 2nd ed. RSC Publishing, Cambridge, UK.

Famelart, M. H., F. Lepesant, F. Gaucheron, Y. Le Graet, and P. Schuck. 1996. pH-induced physicochemical modifications of native phosphocaseinate suspensions: Influence of aqueous phase. Lait $76: 445-460$.

Fan, T. W.-M. 1996. Metabolite profiling by one- and two-dimensional NMR analysis of complex mixtures. Progress in Nuclear Magnetic Resonance Spectroscopy 28:161-219.

FAO/WHO (Food and Agriculture Organization of the United Nations/World Health Organization). 2010. Standard for Fermented Milks, revised standard. Codex Alimentarius. STAN 243-2003. Food and Agriculture Organization of the United Nations, World Health Organization. Accessed Aug. 12, 2012. http://www.codexalimentarius.org/standards/list-of-standards/en.

Fox, P. F., and A. L. Kelly. 2003. Developments in the chemistry and technology of milk proteins. 2. Minor milk proteins. Food Aust. $55: 231-234$.

Fox, P. F., and P. L. H. McSweeney. 1998. Dairy Chemistry and Biochemistry. Chapman and Hall, London, UK.

Gastaldi, E., A. Lagaude, S. Marchesseau, and B. Tarodo de la Fuente. 1997. Acid milk gel formation as affected by total solids content. J. Food Sci. 62:671-675.

Grunert, K. G., T. Bech-Larsen, and L. Bredahl. 2000. Three issues in consumer quality perception and acceptance of dairy products. Int. Dairy J. 10:575-584.

Güzel-Seydim, Z. B., A. C. Seydim, A. K. Greene, and A. B. Bodine. 2000. Determination of organic acids and volatile flavor substances in kefir during fermentation. J. Food Compost. Anal. 13:35-43.

ISO (International Organization for Standardization). 2012. Fermented milks - Determination of titratable acidity. Potentiometric method. ISO/TS 11869. ISO, Geneva, Switzerland.

Lucey, J. A. 2002. Formation and physical properties of milk protein gels. J. Dairy Sci. 85:281-294.

Malz, F., and H. Jancke. 2005. Validation of quantitative NMR. J. Pharm. Biomed. Anal. 38:813-823.

Matsuda, R., Y. Hayashi, C. Yomota, Y. Tagashira, M. Katsumine, and K. Iwaki. 2001. Statistical and probabilistic approaches to confidence intervals of linear calibration in liquid chromatography. Analyst 126:2061-2065.

Miller, J. C., and J. N. Miller. 1988. Statistics for Analytical Chemistry. Ellis Horwood, Chichester, UK.

Oldfield, D. J., H. Singh, M. W. Taylor, and K. N. Pearce. 1998. Kinetics of denaturation and aggregation of whey proteins in skim milk heated in an ultra-high temperature (UHT) pilot plant. Int. Dairy J. 8:311-318.

Özen, S., and M. Özilgen. 1992. Effects of substrate concentration on growth and lactic acid production by mixed cultures of Lactobacillus bulgaricus and Streptococcus thermophilus. J. Chem. Technol. Biotechnol. 54:57-61.
Payot, T., Z. Chemaly, and M. Fick. 1999. Lactic acid production by Bacillus coagulans: kinetic studies and optimization of culture medium for batch and continuous fermentations. Enzyme Microb. Technol. 24:191-199.

Pernoud, S., N. Schneid-Citrain, V. Agnetti, S. Breton, J.-M. Faurie, L. Marchal, D. Obis, E. Oudot, D. Paquet, and T. Robinson. 2005 Application des bactéries lactiques dans les produits laitiers frais et effets probiotiques. Pages 25-37 and 51-66 in Bactéries lactiques et probiotiques. F.-M. Luquet and G. Corrieu, ed. Editions Tec \& Doc - Lavoisier, Paris, France.

Sadler, G. D., and P. A. Murphy. 2010. pH and Titratable Acidity. Pages 219-238 in Food Analysis. S. S. Nielsen, ed. Springer, New York, NY.

Salaün, F., B. Mietton, and F. Gaucheron. 2005. Buffering capacity of dairy products. Int. Dairy J. 15:95-109.

Schepers, A. W., J. Thibault, and C. Lacroix. 2002. Lactobacillus helveticus growth and lactic acid production during $\mathrm{pH}$-controlled batch cultures in whey permeate/yeast extract medium. Part II: Kinetic modeling and model validation. Enzyme Microb. Technol. 30:187-194.

Silvestre, V., S. Goupry, M. Trierweiler, R. Robins, and S. Akoka 2001. Determination of substrate and product concentrations in lactic acid bacterial fermentations by proton NMR using the ERETIC method. Anal. Chem. 73:1862-1868.

Sodini, I., and C. Béal. 2003. Fabrication des yaourts et des laits fermentés. Techniques de l'Ingénieur, traité Agroalimentaire, Vol. TI140. No. F6315. Techniques de l'Ingénieur, Paris, France.

Tamime, A. Y., and R. K. Robinson. 1999. Yoghurt Science and Technology. 2nd ed. Woodhead Publishing, Cambridge, UK.

Tardieu, A., W. De Man, and H. This. 2010. Using one-dimensional (1D) and two-dimensional (2D) quantitative proton $\left({ }^{1} \mathrm{H}\right)$ nuclear magnetic resonance spectroscopy (q NMR) for the identification and quantification of taste compounds in raw onion (Allium cepa L.) bulbs and in aqueous solutions where onion tissues are soaked. Anal. Bioanal. Chem. 398:3139-3153.

Tardieu, A., A. Guerez, S. Phana, W. de Man, and H. This. 2009 Comparison of mono- and di-saccharides release in aqueous solutions by raw or fried dice of onion (Allium cepa L.) bulbs using quantitative nuclear magnetic resonance (qNMR). J. Food Sci 74:C319-C325.

Torrestiana, B. S., E. Brito de la Fuente, C. Lacroix, and L. Choplin. 1994. Modelling the acidifying activity profile of Lactobacillus bulgaricus cultures. Appl. Microbiol. Biotechnol. 41:192-196.

Vetier, N., S. Banon, J. P. Ramet, and J. Hardy. 2000. Casein micelle solvation and fractal structure of milk aggregates and gels. Lait 80:237-246.

Vollhardt, K. P. C., and N. E. Shore. 1995. Traité de chimie organique. De Boeck, Brussels, Belgium.

Weberskirch, L., A. Luna, S. Skoglund, and H. This. 2011. Comparison of two liquid-state NMR methods for the determination of saccharides in carrot (Daucus carota L.) roots. Anal. Bioanal. Chem. 399:483-487.

Wrolstad, R. E. 2005. Handbook of Food Analytical Chemistry. Vol. II. 1st ed. John Wiley \& Sons, Hoboken, NJ. 